\title{
Aquaspirillum magnetotacticum sp. nov., a Magnetic Spirillum
}

\author{
D. MARATEA AND R. P. BLAKEMORE \\ Department of Microbiology, University of New Hampshire, Durham, New Hampshire 03824
}

We studied the taxonomically relevant characteristics of a microaerophilic, chemoheterotrophic, magnetotactic, freshwater spirillum. Our results indicated that this organism represents a new bacterial species, which is most appropriately placed in the genus Aquaspirillum despite its microaerophilic nature and its lack of detectable catalase and oxidase activities. The name proposed for this new species is Aquaspirillum magnetotacticum, which reflects the remarkable magnetic responsiveness of this organism. The type strain is MS-1 (= ATCC 31632).

Diverse morphological types of magnetotactic bacteria have been found in aquatic sediments throughout the world $(2-4,16)$. The magnetic orientation of these bacteria is due to cytoplasmic, enveloped, electron-dense, magnetic particles called magnetosomes $(1,9)$. One of these unusual bacteria, a microaerophilic spirillum designated strain MS-1, was isolated from a freshwater swamp and has been grown in pure culture in a chemically defined medium. The cells of this bacterium were partially characterized, and despite their ability to synthesize magnetosomes, they resembled the cells of members of the genus Aquaspirillum in that they were nonmarine, heterotrophic, gram negative, and helical with bipolar flagella (5). In this paper we describe the results of a taxonomic study of this organism.

(Some of the results have been presented previously [R. P. Blakemore, R. S. Wolfe, and D. Maratea, Abstr. Annu. Meet. Am. Soc. Microbiol. 1979, N38, p. 185].)

\section{MATERIALS AND METHODS}

Bacterial strains and culture conditions. The organisms used in this study were the magnetic spirillum strain MS-1 and a cloned, nonmagnetic line derived from strain MS-1. The isolation and culture methods, the results of a partial characterization study (5), and the ultrastructures (1) of magnetic and nonmagnetic forms of strain MS-1 have been described previously. Stock cultures were frozen in $10 \%$ dimethyl sulfoxide as a cryoprotectant or were maintained at $30^{\circ} \mathrm{C}$ in semisolid growth medium or in a chemically defined medium, as described previously (5). Growth media were modified by substituting $0.08 \%(\mathrm{wt} / \mathrm{vol})$ $\mathbf{L}-(+)$-tartaric acid for succinic acid and omitting sodium acetate. Cells of strain MS-1 were also cultured aerobically in petri dishes containing $30 \mathrm{U}$ of catalase per $\mathrm{ml}$ and microaerobically in desiccator jars containing a $70 \% \mathrm{~N}_{2}-30 \%$ air atmosphere. Nonmagnetic cells were cultured in 250-ml Erlenmeyer flasks, each of which contained $100 \mathrm{ml}$ of chemically defined growth medium without sodium thioglycolate or catalase. These flasks were incubated on a rotating shaker at $160 \mathrm{rpm}$.

Biochemical characteristics. The guanine-pluscytosine contents of extracted deoxyribonucleic acids, the catalase and oxidase contents of the cells, the ability of the cells to use various compounds as sole carbon sources, to reduce nitrate to nitrous oxide, and to produce $\mathrm{NH}_{3}$, and the inability of the cells to grow anaerobically with sodium nitrate have been reported previously $(5,11)$. Cells were tested for oxidase activity (15) before and after treatment with toluene. Semisolid growth medium lacking resazurin but supplemented with appropriate substances was used to measure $\mathrm{H}_{2} \mathrm{~S}$ production from $0.2 \%(\mathrm{wt} / \mathrm{vol})$ L-cysteine (12), the reduction of $0.3 \%$ (wt/vol) sodium selenite (12), and indole production from $0.1 \%$ (wt/vol) Trypticase (BBL Microbiology Systems). Indole production was determined with Ehrlich reagent (8) and with cultures of Salmonella sp. serovar minnesota and Escherichia coli B as negative and positive controls, respectively. The sensitivities of the organisms to $1 \%$ (wt/vol) oxgall bile (Difco Laboratories), 1\% (wt/vol) glycine, $1 \%$ (wt/vol) sodium chloride, and $0.008 \%$ (wt/ vol) potassium cyanide were determined by observing growth responses in semisolid growth medium for 2 weeks. The ability to hydrolyze sodium hippurate (10), casein (10), or soluble starch (13) when each was supplied in a semisolid growth medium at a final concentration of $1 \%(\mathrm{wt} / \mathrm{vol})$ was determined after 1 week of growth. The hydrolysis of $0.5 \%$ (wt/vol) esculin (15) by growing cells was determined by using a similar adaptation of the standard procedures to microaerobic growth conditions with semisolid media. The hydrolysis of gelatin was determined by supplementing a chemically defined medium with $12 \%$ (wt/ vol) gelatin (Difco). Pseudomonas maltophilia was used as a positive control. Liquefaction was determined after cooling to $4^{\circ} \mathrm{C}$. Soluble pigment production was determined with cells grown in a semisolid growth medium containing $0.5 \%$ (wt/vol) L-tyrosine, L-phenylalanine, or L-tryptophane. Fluorescent pigment production was determined by viewing liquid cultures in ultraviolet light.

Urease activity was determined by observing pH changes with washed cell suspensions in BES buffer 
(12). Proteus vulgaris was used as a positive control. The phosphatase and sulfatase activities of concentrated cell suspensions were tested after incubation for $6 \mathrm{~h}$ at $31^{\circ} \mathrm{C}$ with $0.05 \%$ (wt/vol) sodium phenolphthalein diphosphate and potassium phenolphthalein disulfate (Sigma Chemical Co.), respectively. Immediate formation of a pink color after 1 drop of $10 \mathrm{~N} \mathrm{NaOH}$ was added indicated a positive test (15). P. vulgaris was used as a positive control for each test.

The ability of cells to grow in peptone succinate salts medium (14) and modified peptone succinate salts medium (6) was assessed by using semisolid forms of these media in screw-capped culture tubes with and without added sodium thioglycolate. Cells were also inoculated into liquid forms of these media under aerobic or microaerobic conditions. Cells were tested for the ability to grow and to produce acid in the presence of glucose, sucrose, or maltose, each of which was added to a chemically defined growth medium. The sugars were added to final concentrations of 0.5 and $1.0 \%(\mathrm{wt} / \mathrm{vol})$, and the $\mathrm{pH}$ values before and after growth were measured with an electrode. Cells were also inoculated into a chemically defined growth medium modified so that any one of a variety of carbohydrates was the sole carbon source (5).

Cells were tested for the ability to grow on differential media, including eosin methylene blue agar (BBL) and MacConkey agar (BBL) in petri dishes and triple sugar iron agar (BBL) in tubes inoculated by streaking and stabbing. To allow growth of surface colonies, these media were supplemented with $30 \mathrm{U}$ of catalase per $\mathrm{ml}$ and incubated aerobically.

Freshly autoclaved tubes of litmus milk (Fisher Scientific Co.) in which oxygen gradients had formed were inoculated and examined for alkaline reactions over a 2-week period.

\section{RESULTS}

As described previously (5), cells of strain MS1 are small, helical, gram negative, and of freshwater origin (Fig. 1). They have deoxyribonucleic acid base composition of $64.5 \mathrm{~mol} \%$ guanine plus cytosine. This organism is chemoheterotrophic but does not use carbohydrates or amino acids as sole carbon and energy sources. Optimal growth occurs microaerobically at $30^{\circ} \mathrm{C}$ in a simple, defined medium containing any one of several tricarboxylic acid cycle intermediates as a carbon source. Under these conditions, the quantity of nitrate reduced to nitrous oxide by growing cells corresponds to the amount of substrate oxidized to $\mathrm{CO}_{2}$. However, a small amount of oxygen is also required for growth (11).

Our results indicated that strain MS-1 does not hydrolyze casein, starch, or hippurate, does not produce indole from tryptophane, and is phosphatase positive and sulfatase negative. Intracytoplasmic granules resembling poly- $\beta$-hydroxybutyric acid are often quite numerous within cells. Coccoid bodies are formed late in growth or under adverse culture conditions. Surface colonies grown aerobically (with catalase)

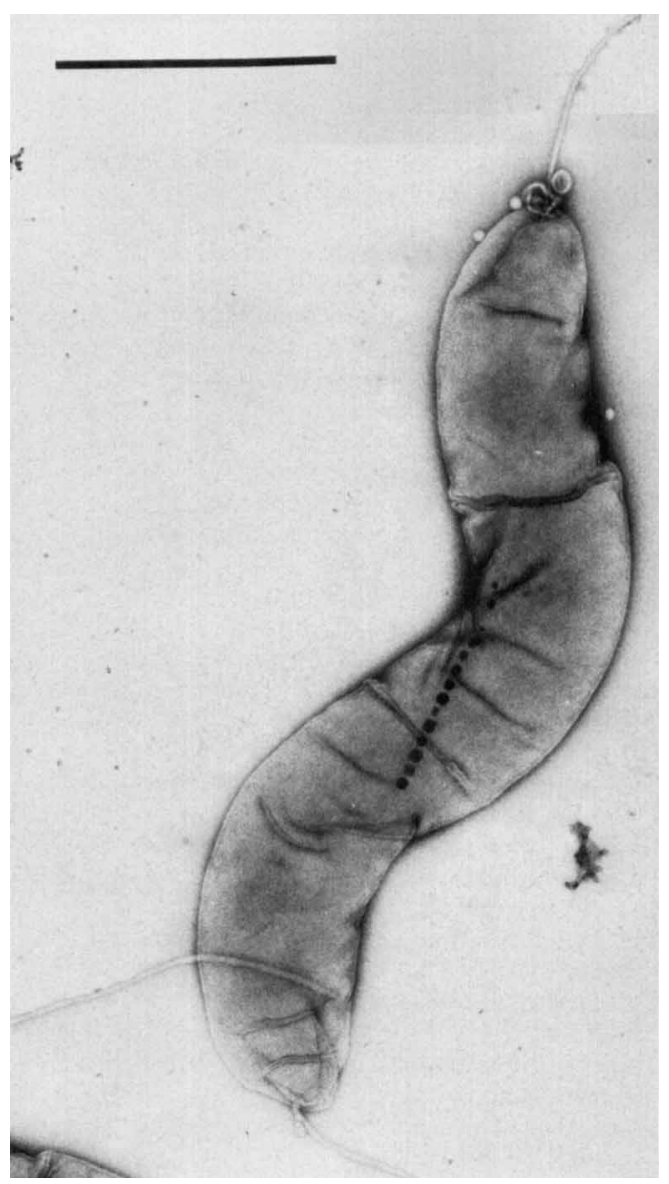

FIG. 1. Electron micrograph of a magnetotactic cell of A. magnetotacticum strain MS-1 stained with uranyl acetate. Bar $=1.0 \mu \mathrm{m}$.

or microaerobically are pinpoint, rough edged, and translucent. Aerobically grown cells are not magnetotactic. Although untreated cells give a negative oxidase test, toluene-treated cells give a faintly positive delayed-type test (15).

The biological and biochemical characteristics of strain MS-1 are shown in Table 1. The magnetotactic and non-magnetotactic cells are identical except in those characteristics that are related to magnetism, such as the presence of magnetosomes and magnetically directed swimming behavior.

\section{DISCUSSION}

As pointed out by H. G. D. Niekus (Ph.D. thesis, Vrije University, Amsterdam, The Netherlands, 1980), the high guanine-plus-cytosine content of the deoxyribonucleic acid of strain MS-1 is an exception to the general rule that microaerophiles have low guanine-plus-cytosine 
TABLE 1. Characteristics of strain MS-1 ${ }^{a}$

\begin{tabular}{|c|c|}
\hline Characteristic $^{b}$ & Reaction $^{c}$ \\
\hline Catalase activity & - \\
\hline Oxidase activity .... & $-^{d}$ \\
\hline Phosphatase activity & + \\
\hline Urease activity ..... & - \\
\hline Sulfatase activity $\ldots \ldots \ldots \ldots \ldots \ldots$ & - \\
\hline $\begin{array}{l}\text { Hydrolysis of casein, starch, hippurate, and } \\
\text { esculin }\end{array}$ & - \\
\hline $\begin{array}{l}\text { Nitrate reduction with accumulation of } \\
\text { nitrite }\end{array}$ & - \\
\hline Nitrate reduced beyond the nitrite stage & + \\
\hline Ammonia produced during growth $\ldots \ldots$ & + \\
\hline Anaerobic growth with nitrate $\ldots$ & - \\
\hline Gelatin liquefaction within 10 days $\ldots \ldots$ & - \\
\hline Indole production from tryptophane $\ldots$. & - \\
\hline $\begin{array}{l}\text { Hydrogen sulfide production from cys- } \\
\text { teine }\end{array}$ & - \\
\hline Alkaline reaction in litmus milk . . . . . . & - \\
\hline Acid reaction from carbohydrates . . . . . . & - \\
\hline Growth in the presence of $1 \%$ bile $\ldots$ & - \\
\hline Growth in the presence of $1 \%$ glycine & + \\
\hline Growth in the presence of $\mathrm{KCN}$ & - \\
\hline Growth in the presence of $1 \% \mathrm{NaCl} \ldots \ldots$ & - \\
\hline $\begin{array}{l}\text { Growth on eosin methylene blue or Mac- } \\
\text { Conkey agar }\end{array}$ & - \\
\hline $\begin{array}{l}\text { Growth in peptone succinate salts me- } \\
\text { dium }\end{array}$ & \pm \\
\hline Growth in triple sugar iron medium $\ldots .$. & - \\
\hline $\begin{array}{l}\text { Pigment formation from aromatic amino } \\
\text { acids } \ldots \ldots \ldots \ldots \ldots \ldots \ldots \ldots\end{array}$ & - \\
\hline 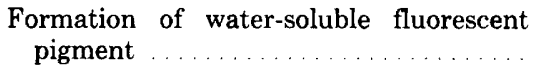 & - \\
\hline $\begin{array}{l}\text { Presence of intracellular poly- } \beta \text {-hydroxy- } \\
\text { butyric acid }\end{array}$ & + \\
\hline $\begin{array}{l}\text { Formation of coccoid bodies in older cul- } \\
\text { tures }\end{array}$ & + \\
\hline Selenite reduction $\ldots \ldots \ldots \ldots \ldots \ldots$ & - \\
\hline
\end{tabular}

${ }^{a}$ In addition, the cells were 0.2 to $0.4 \mu \mathrm{m}$ in diameter, the flagella were single and bipolar, the guanine-pluscytosine content of the deoxyribonucleic acid was 64.5 mol\%, and the optimal growth temperature was $30^{\circ} \mathrm{C}$.

${ }^{b}$ For test procedures, see text.

${ }^{c}+$, Positive result; - , negative result; \pm , variable result.

${ }^{d}$ Faintly positive delayed test when the cells were treated with toluene.

contents. Based on their small size, high guanine-plus-cytosine content, and single bipolar flagellation pattern, strain MS-1 cells are similar to cells of $A$. polymorphum (12). In contrast, however, $A$. polymorphum is phosphatase negative, hydrolyzes esculin, and does not reduce nitrate beyond the nitrite stage (12). Strain MS1 grows in the presence of $1 \%$ glycine, a characteristic shared only by Aquaspirillum dispar and Aquaspirillum aquaticum (12). Like $A q$ uaspirillum delicatum and Aquaspirillum anulus, strain MS-1 does not grow in the presence of $1 \%$ bile (12). Of the known members of $A q$ uaspirillum, only a strain of Aquaspirillum gies- bergeri (previously "Spirillum graniferum" NCIB 8230 ) does not produce hydrogen sulfide from cysteine (12). The growth of strain MS-1 was inhibited by cysteine in the medium; this could have resulted from a toxic accumulation of hydrogen peroxide produced when cysteine was exposed to atmospheric oxygen at the surface of the semisolid medium (7).

We should point out that whereas most of the biochemical tests reported by other workers for Spirillum and Aquaspirillum species were carried out with cells grown in media containing peptone, succinate, and salts (12), cells of strain MS-1 grew variably in such a medium and were not magnetotactic. Consequently, in this study we used a simple, chemically defined medium in which strain MS-1 grew best.

Strain MS-1 differs from other members of the genus Aquaspirillum principally in its lack of detectable catalase activity and in its ability to synthesize magnetite $\left(\mathrm{Fe}_{3} \mathrm{O}_{4}\right)$, resulting in its magnetotactic behavior. Since magnetotaxis is a characteristic of very diverse morphological types of bacteria found in ecologically diverse habitats, we consider magnetite synthesis alone, like methanogenesis, nitrogen fixation, or $\mathrm{H}_{2}$ autotrophism alone, to be an insufficient criterion for separation of taxa at the generic level.

In conclusion, strain MS-1 shares many relevant taxonomic characteristics with the genus Aquaspirillum as described by Hylemon et al. (12). We propose the name Aquaspirillum mag. netotacticum sp. nov. for strain MS-1 and similar organisms. A description of this new species follows.

Aquaspirillum magnetotacticum sp. nov. (mag ne to tac'ti cum. Gr. n. magnes magnet, comb. form magneto-; Gr. adj. taktikos showing orientation or movement directed by a force or agent; magnetotacticum capable of orientation with respect to a magnet).

Helical (clockwise) spirilla, 0.2 to 0.4 by 4.0 to $6.0 \mu \mathrm{m}$, with a tendency to form long chains and coccoid bodies in older cultures; the wavelength is 1 to $2 \mu \mathrm{m}$. Gram negative. Motile by means of a single flagellum at each pole. Each magnetotactic cell contains a variable number of enveloped magnetite $\left(\mathrm{Fe}_{3} \mathrm{O}_{4}\right)$ particles arranged in a chain within the cytoplasm; each particle (magnetosome) is approximately 40 to $50 \mathrm{~nm}$ on a side. Intracytoplasmic granules presumed to be poly- $\beta$-hydroxybutyrate are present. Optimal growth occurs at $30^{\circ} \mathrm{C}$. Chemoheterotrophic. Microaerophilic. Growth in the presence of KCN is inhibited. Cannot grow anaerobically with nitrate. Does not hydrolyze casein, starch, hippurate, esculin, or gelatin. Selenite is not reduced. Hydrogen sulfide is not produced from cysteine. Catalase, oxidase, urease, sulfatase, and indole 
are negative. Oxidase test is faintly positive with toluene-treated cells. Phosphatase is positive. There is no alkaline reaction in litmus milk. Grows in the presence of $1 \%$ glycine, but growth is inhibited by $1 \%$ bile or $1 \% \mathrm{NaCl}$. No pigment is produced from aromatic amino acids. A watersoluble fluorescent pigment is not produced. Nitrate is reduced to nitrous oxide without nitrite accumulation. Ammonia is formed during growth in nitrate-containing medium. A variety of tricarboxylic acid cycle intermediates are used as sole carbon sources. Carbohydrates are not used as sole carbon sources. Nitrate and ammonium ions are utilized as nitrogen sources. The guanine-plus-cytosine content of the deoxyribonucleic acid is $64.5 \mathrm{~mol} \%$.

Source: isolated by R.P.B. at the University of Illinois from sediments collected in Cedar Swamp, Woods Hole, Mass.

Type strain: strain MS-1. A culture of strain MS-1 has been deposited with the American Type Culture Collection under the number ATCC 31632 . Since at present the type strain is the only known strain in the species, the description of the type strain is the same as that for the species.

\section{ACKNOWLEDGMENTS}

We gratefully acknowledge the valuable technical assistance of Joyce Tugel and Nancy Blakemore. D. L. Balkwill provided expert assistance with electron microscopy.

This work was supported by grant PCM-7922224 from the National Science Foundation and by contract N00014-80-C0029 with the Office of Naval Research.

\section{REPRINT REQUESTS}

Address reprint requests to: R. P. Blakemore, Department of Microbiology, University of New Hampshire, Durham, NH 03824

\section{LITERATURE CITED}

1. Balkwill, D. L., D. Maratea, and R. P. Blakemore. 1980. Ultrastructure of a magnetotactic spirillum. J. Bacteriol. 141:1399-1408.
2. Blakemore, R. P. 1975. Magnetotactic bacteria. Science 190:377-379.

3. Blakemore, R. P., R. B. Frankel, and A. J. Kalmijn. 1980. South-seeking magnetotactic bacteria in the southern hemisphere. Nature (London) 286:384-385.

4. Blakemore, R. P., R. B. Frankel, and R. S. Wolfe. 1979. Ferromagnetism in freshwater bacteria, p. 400407. In R. D. Phillips, M. F. Gillis, W. T. Kaune, and D. D. Mahlum (ed.), Biological effects of extremely low frequency electromagnetic fields. Proceedings of the 18th Annual Hanford Life Sciences Symposium. Technical Information Center, U.S. Department of Energy, Washington, D.C.

5. Blakemore, R. P., D. Maratea, and R. S. Wolfe. 1979. Isolation and pure culture of a freshwater magnetic spirillum in chemically defined medium. J. Bacteriol. 140:720-729.

6. Caraway, B. H., and N. R. Krieg. 1972. Uncoordination and recoordination in Spirillum volutans. Can. J. Microbiol. 18:1749-1759.

7. Carlsson, J., G. P. D. Granberg, G. K. Nyberg, and M.-B. K. Edlund. 1979. Bactericidal effect of cysteine exposed to atmospheric oxygen. Appl. Environ. Microbiol. 37:383-390.

8. Cowan, S. T., and K. J. Steel. 1974. Manual for the identification of medical bacteria. Cambridge University Press, New York.

9. Denham, C. R., R. P. Blakemore, and R. B. Frankel. 1980. Bulk magnetic properties of magnetotactic bacteria. IEEE Trans. Magn. 16:1006-1007.

10. Department of the Army. 1963. Laboratory procedures in clinical bacteriology. Technical manual TM8-227-5. Department of the Army, Washington, D.C.

11. Escalante-Semerena, J. C., R. P. Blakemore, and R. S. Wolfe. 1980. Nitrate dissimilation under microaerophilic conditions by a magnetic spirillum. Appl. Environ. Microbiol. 40:429-430.

12. Hylemon, P. B., J. S. Wells, N. R. Kreig, and H. W. Jannasch. 1973. The genus Spirillum: a taxonomic study. Int. J. Syst. Bacteriol. 23:340-380.

13. Lennette, E. H., E. H. Spaulding, and J. P. Truant (ed.). 1974. Manual of clinical microbiology, 2nd ed. American Society for Microbiology, Washington, D.C.

14. McElroy, L. J., J. S. Wells, Jr., and N. R. Krieg. 1967. Mode of extension of cell surface during growth of Spirillum volutans. J. Bacteriol. 93:499-501.

15. McFaddin, J. 1976. Biochemical tests for identification of medical bacteria. The Williams \& Wilkins Co., Baltimore.

16. Moench, T. T., and W. A. Konetzka. 1978. A novel method for the isolation and study of a magnetotactic bacterium. Arch. Microbiol. 119:203-212. 